時間領域差分 (FDTD) 法による工場建屋内電磁環境のモデリング

正員 趙 孟佑* 非会員 大谷 洋平*
非会員 林
克一**

\title{
Modeling of Electromagnetic Environment Inside a Factory Building via Finite Difference Time Domain Method
}

Mengu Cho*, Member, Youhei Ohtani*, Non-member, Katsuichi Hayashi**, Non-member

\begin{abstract}
Increased use of factory automation (FA) apparatus raises concern over electromagnetic interference among electronic devices at the industrial sites. The purpose of the present paper is to discuss modeling of electromagnetic environment inside a factory building via Finite Difference Time Domain (FDTD) method. The principal noise frequency radiated by an inverter-motor system in the building is between $1 \mathrm{MHz}$ and $10 \mathrm{MHz}$. Three-dimensional simulation code is verified against measurement of magnetic field distribution inside a simulated building and a laboratory. Effect of wire reinforced concrete wall on the numerical modeling is discussed. As long as the noise source is far away from the wall, the reinforced concrete wall can be modeled as a simple metallic wall reflecting the electromagnetic wave of the frequencies between $1 \mathrm{MHz}$ and $10 \mathrm{MHz}$. When the noise source is embedded inside the wall, however, each reinforcing wire must be modeled.
\end{abstract}

キーワード : FDTD 法, 電磁界解析, 電磁ノイズ, スイッチング機器, EMC, 鉄筋コンクリート

Keywords : FDTD method, electromagnetic field analysis, electromagnetic noise, switching device, EMC, reinforced concrete

\section{1. まえがき}

工場内での FA(Factory Automation)機器の使用が拡大・多 用化すると共に，電子回路の高集積化，低電圧化が進むに つれて, 電子機器の電磁ノイズによる誝作動が問題となっ ている。大電力モータを使用する産業現場においては，誤 作動によるライン停止や不良品製造による経済的損失を抑 える必要があり, 効果的なノイズ対策が求められている。 しかしながら, 産業現場において実際にラインの稼働中に ノイズ発生源を突き止めることは，経済上及び安全上の観 点から難しい。活線に流れる伝導ノイズ電流の測定やアン テナによる放射ノイズの測定は，例え可能であっても，測 定点は安全・保安上の問題から限られたものとなる。

本研究の目指寸ところは, 数值解析による工場建屋内の 電磁ノイズ環境（特に放射ノイズ環境）のマッピングッー ルを開発することにある。基本方針としては,

(1) 既知のノイズ発生源から出る放射ノイズの伝搬・分 布を正確に再現できる数值解析コードの開発

\footnotetext{
* 九州工業大学

干804-8550 北九州市戸畑区仙水 1-1

Kyushu Institute of Technology

1-1 Sensui, Tobata-ku, Kitakyushu 804-8550

**ナスコ(株)

干206-0025 多摩市永山 6-17-8

NUSCO Co., Ltd.

6-17-8 Nagayama, Tama 206-0025
}

（2）限られた測定データから未知のノイズ発生源を特 定する数值解析コードの開発

（3）特定されたノイズ発生源が作り出す建屋内の未測 定点での電磁環境の推定をできる数值解析コードの開発 の順に開発を進めていく。このうち(1)と(3)は既知の放射源 から電磁界分布を求める順問題であり, 同じ計算手法とな る。本研究では(1)と(3)の部分に時間領域差分法(Finite Difference Time Domain, 以下 FDTD 法) $)^{(1)(2)}$ 適用する。(2) は逆問題であり, 何らかの最適化手法が必要となる。電磁 ノイズのマッピングをこのような数值解析で行う利点は, 実際に稼働中の工場内の限られた場所にアンテナを立てて ノイズ測定をするだけで発生源を特定できること，及び一 旦ノイズ源を特定すれば機器配置換えや遮蔽等の対策の効 果を速やかに検討可能であることにある。電磁環境のマッ ピングツールの開発にあたっては, 様々な課題があるが, 本稿では順問題の(1),(3) に相当する FDTD 法の開発を行っ た結果について報告する。電磁界解析手法として FDTD 法 自体は既に新しい手法ではないが，本稿では工場建屋内の 電磁環境を FDTD 法によってモデリングする際の課題を検 討することを主眼としている。

本稿の 2 章では, 計算コードの開発に入る前に, 計算対 象の周波数帯域を特定するために行った実験結果について 報告する。本研究で対象とするのは大電力モータ等で駆動 
される機器が多く存在する産業現場であり, 伝導・放射ノ イズの主要因はインバータと交流電動機から構成されるシ ステムでのスイッチングに起因して発生するノイズである と考える。インバータ-モータ系でのノイズ電流については, 過去に小笠原ら ${ }^{(3)(4)}$ の研究において, インバータのスイッチ ングに起因したインバータ出力のステップ変化がモータ駆 動電流に伝導ノイズとして重畳され，モータ巻き線と接地 間の浮遊容量を介してコモンモードノイズ電流として流れ ることが発生要因であると報告されている。本稿では，実 際に出力 $200 \mathrm{~W}$ の小型のインバータとモータを実験対象と して, 電流プローブによって各部を流れるノイズ電流を計 測すると共に放射磁界を計測することで主要な周波数帯域 を明らかにする。

3 章においては計算コードの検証実験について述べる。白 川(5)等はアンテナ理論に基づいたモーメント法によってイ ンバータ・モータ駆動系からの放射電磁界を計算したが, 本研究では矩形グリッドという制約はあるもののモデル化 が容易な FDTD 法(1)(2)を用いて放射電磁界の計算を行う。本 研究では建屋内の電磁環境を対象としており, 建屋の中に 放射源があったときに, その内部の電磁界分布がどのよう になっているかを調べる。そこで PML(Perfectly Matched Layer)境界 ${ }^{(1)}$ を外側に配して建屋を模擬した物体を計算領域 内に配した 3 次元の FDTD コードを製作した。また, 建屋 を縮小して模擬した金属製の箱（以降，模擬建物と呼ぶ） を製作しその中に放射ループアンテナを置いて内外の電磁 界分布を測定した。放射電磁波としては，その波長と模擬 建物の大きさの相対比が実際のノイズ波長と建屋の大きさ の相対比に合致するようにした。そのようにした上で，電 磁界分布の測定結果と計算結果を比較することで FDTD コ ードが正確に電磁界分布を計算できているかを検証した。

4 章においては，2 章で用いたインバータ・モータシステ ムから実際に放射される磁界分布のシミュレーション結果 と実測值を比較した結果について述べる。

5 章においては建屋をモデル化する際に, 外壁をどのよう にモデル化すべきかについて調べた結果について述べる。 コンクリートの導電率は水分含有率等の違いによりケース バイケースで異なるが, 参考文献(6)では, 導電率 $\sigma$ が $2.3 \times 10^{-3} \mathrm{~S} / \mathrm{m}$ の半導体として取り扱っている。本稿でも半導 体として取り扱った時に建屋内の電磁環境にどのような影 響を与えるかについて検討する。また，実際には鉄筋が壁 に入っている場合が殁どであるが，格子状に交差した金属 筋で建屋が覆われた時，それが完全遮蔽の金属壁と同様に 扱うことができるかどうかについて検討する。

最後に 6 章においては本論文の結論と今後の課題につい て述べる。

\section{2. 周波数帯域}

研究対象とする周波数帯域を特定するために, $200 \mathrm{~W}$ の ンバータ駆動交流モータを用いてシステム各部の電流を計 測した。図 1 に使用したインバータ駆動交流モータシステ

\section{ムの写真と電流の測定点を示す}

市販の三相 AC サーボモータを対象として測定をおこな った。システム全体はインバータ駆動用 24VDC 電源からの 接地線（図 1 の測定点 1) を介して一点接地されている。測 定で はインバータ出力の UVW 各相と接地閒の電圧を高電 圧プローブ(Sony Tektronix P5100)で計測し, 電流プローブ (Sony Tektronix P6022)でシステム内の各場所の電流を計測 した。高電圧プローブ 3 本と電流プローブ 1 本は 4 チャン ネルディジタルオシロスコープ（Sony Tektornix TDS224）に つないである。オシロスコープのトリガは, モータを 1000rpm で無負荷で回転させながらインバータの UVW3 相 の出力が同時に ON 状態になったときの $\mathrm{W}$ 相の立ち上がり でかけた。測定の結果接地線に流れる電流が最も大きく図 2 のような波形が得られた。

また，同様の波形が測定点 5 のモータへの動力線とモー タの接地線にも流れるが, 両者が撚り線構造となっていて 打ち消しあっている。また, 測定点 3 のインバータとブレ

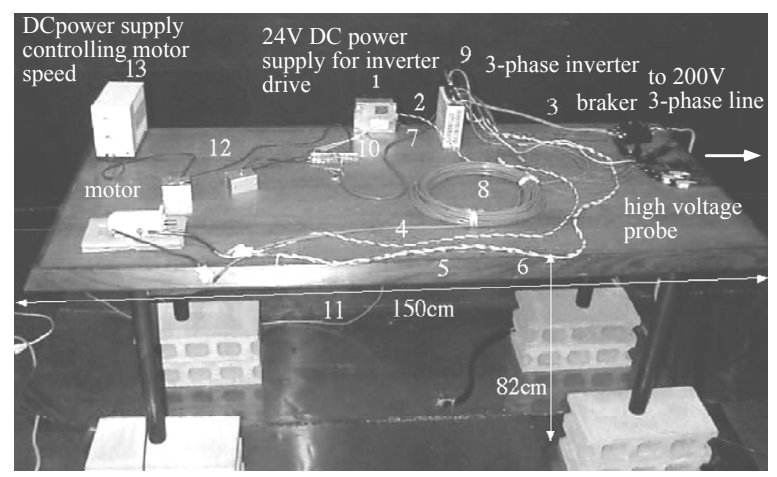

図 1 電流計測に用いたインバータ駆動交流モータ システムの写真（数字は電流の測定場所を表す）

Fig. 1. Photograph of inverter-motor system used for current measurement (numbers denote the position of measurement).

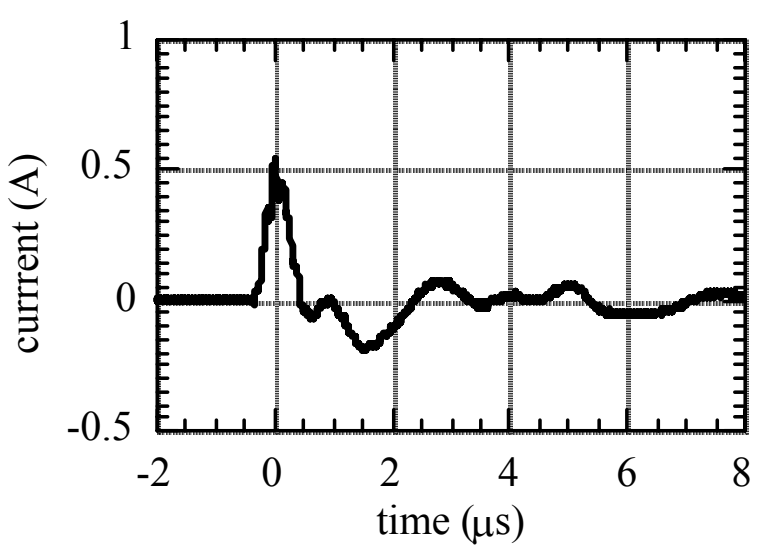

図 2 インバータの三相出力が全て ON となったときに 接地線に流れる電流波形

Fig. 2. Current waveform flowing the ground line when all the three phase outputs of the inverter are turned on. 


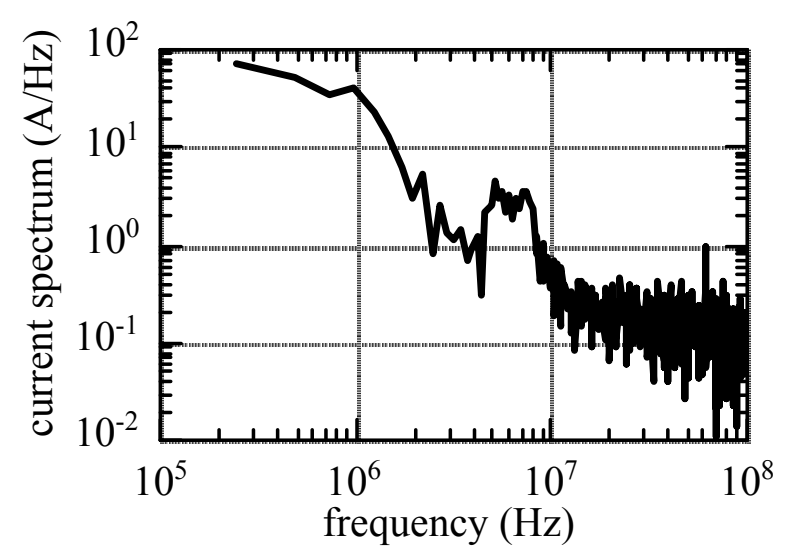

図 3 図 2 の電流波形のフーリエスペクトラム

Fig. 3. Fourier spectrum of current waveform shown in Fig. 2.

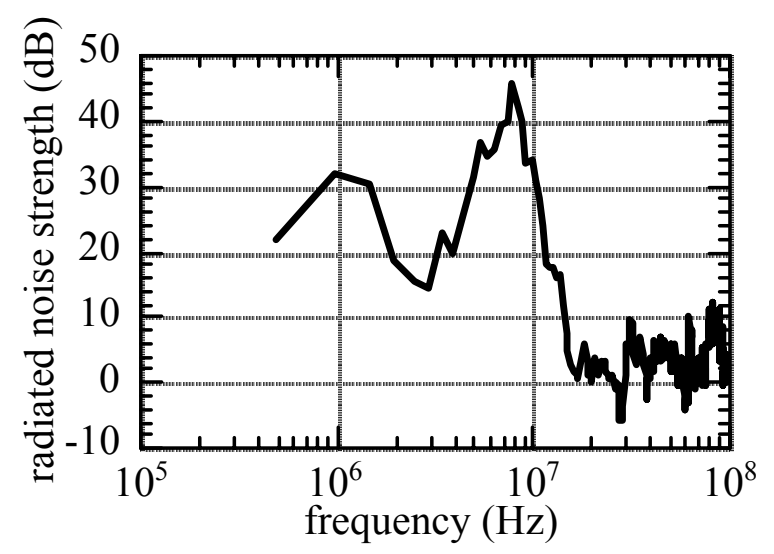

図 4 図 1 のインバータモータシステムから放射される 磁界強度（背景磁界との比をとった $\mathrm{dB}$ 表示）

Fig. 4. Magnetic field strength radiated by the inverter-motor system shown in Fig.1 (shown in $\mathrm{dB}$ normalized by the background magnetic field).

一カ間の電源線にもピーク值は図 2 の $1 / 3$ 程度であるが, 同 様の電流が流れている。これらの測定結果から, 文献(3),

(4)で指摘されているように，インバータがスイッチングを 行うとモータ巻き線とモータフレーム間の浮遊容量を介し て LCR 直列回路にステップ電圧をかけたようなノイズ電流 が流れ，コモンモード電流となってシステム外に流出し， 電源線を介して他の機器にも伝導ノイズとして伝わる。こ のようなノイズ電流成分が，長い経路を伝わって伝搬する 間に，線路がアンテナとして働き放射ノイズを作り出す。

図 3 に図 2 の電流波形をフーリエ変換したものを示す。 $4 \mathrm{MHz}$ から $8 \mathrm{MHz}$ 付近にピークが見られる。図 1 に示したシ ステムからの放射磁界を計測した結果を図 4 に示す。測定 点は図 1 の机の前縁から $0.3 \mathrm{~m}$ 手前で高さ $1 \mathrm{~m}$ の点である。 測定は電磁シールドなどを施していない普通の実験室で行 っているため, モータの非動作時の磁界強度を背景磁界と
する。これに対して何倍磁界強度が上昇したしたかを示し ている。縦軸は $20 \log _{10}\left(H / H_{0}\right)$ であり， $H_{o}$ はモータを動かさ ない時の背景磁界強度である。測定には直径 $15 \mathrm{~cm}$ の自作の ループアンテナを用い, アンテナの電圧出力をディジタル オシロスコープ(Sony Tektronix TDS380P)につないで計測し た。測定された時間波形にフーリエ変換を施してスペクト ラムを算出している。

図 4 にあるように, 電流スペクトラムの強さに応じて, $10 \mathrm{MHz}$ 以下のところで強い磁界放射がある。尚, 出力が $7.5 \mathrm{~kW}$ の大型の $\mathrm{AC}$ サーボモータにおいても同様の測定を 行ったが，同じく $10 \mathrm{MHz}$ 以下のところに強い放射が見られ た。このようなことから, 本研究で対象とする周波数帯域 を放射ノイズの主成分である $1 \mathrm{MHz}$ から $10 \mathrm{MHz}$ に設定し た。

\section{3. 計算コードの検証}

FDTD 法を用いた計算コードを検証するうえで, 実際の建 屋を対象とした計算を行っても良いが，それよりは散乱物 体等の少ないできるだけ簡単な計算対象で, 且つ実験室内 の机上で検証実験を行えるものが望ましい。そこで, 波長 と建屋長さの比を現実と同じに保ったまま，全体の大きさ を机の上にのるくらいにまで縮小した模擬建物を製作し た。その内外での磁界強度分布を測定して, 計算結果の検 証を行う。前章で述べたように, 解析対象の周波数帯域が $1 \mathrm{MHz}$ から $10 \mathrm{MHz}$ であるので, 工場建屋の一辺の代表的長 さ $L$ を $10 \mathrm{~m}$ から $100 \mathrm{~m}$ とすると, 波長 $\lambda$ と建屋長さ $L$ の比 $L / \lambda$ は 0.03 から 3 程度である。机上にのる大きさとして一 辺 $0.6 \mathrm{~m}$ の模擬建物を考えることとし, 波長が $20 \mathrm{~m}$ から $0.2 \mathrm{~m}$ 程度の電磁波を考えれば, 比 $L / \lambda$ を実際と合わせることが できる。

図 5 に検証に用いた計算領域を示す。一辺 $0.015 \mathrm{~m}$ の立方 体グリッドで $0.75 \mathrm{~m} \times 0.75 \mathrm{~m} \times 1.815 \mathrm{~m}$ の大きさの空間を 50 $\times 50 \times 121$ のグリッドに分割する。前後左右及び上方の境界 では吸収境界条件として 7 グリッドの PML(Perfectly Matched Layer)層 ${ }^{(1)}$ を配置した。よって，総グリッド数は 64 $\times 64 \times 128$ である。PML 層内では導電率が 0 から $0.00265 \mathrm{~S} / \mathrm{m}$ まで直線的に変化するように設定した。PML 層内の導電率 の最大值や厚みは試行錯誤の結果, 最も反射波による誤差 が小さくなるように選んだ。

下方の境界は完全導体を想定して，反射境界としている。 領域の中心には 1 辺 $0.09 \mathrm{~m}$ の矩形のループアンテナを配し, 下辺の中央に給電点を持っている。ループアンテナを取り 囲むように，一辺 $0.6 \mathrm{~m}$ の立方体の模擬建物を配している。 模擬建物の+y 方向の壁には $0.3 \mathrm{~m} \times 0.3 \mathrm{~m}$ の空を空けている。 模擬建物の壁はアルミニウム $\left(\right.$ 導電率 $\left.\sigma=3.5 \times 10^{7} \mathrm{~S} / \mathrm{m}\right)$ を仮定 し, 壁は窓のない面は 1 グリッド分, ある面は 2 グリッド 分の厚みをもっている。

FDTD 法は以下の二つの Maxwell 方程式を差分により解 くものであり, 差分方法は文献(1)に詳述されている Yee ア ルゴリズムを使っている。 

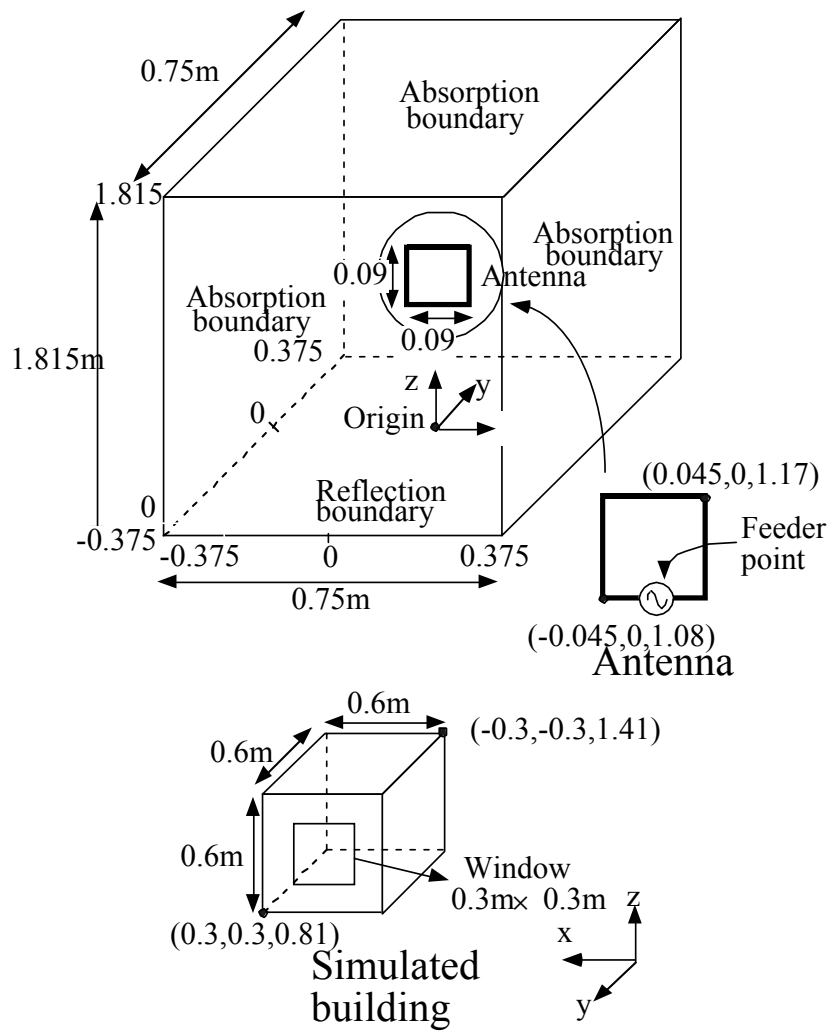

図 5 計算コードの検証のための計算領域（PML 層を除く）

Fig. 5. Computational domain used for verification of numerical code (excluding PML layer).

$$
\begin{aligned}
& \frac{\partial \vec{E}}{\partial t}=-\frac{\sigma}{\varepsilon} \vec{E}-\frac{1}{\varepsilon} \vec{j}+\frac{1}{\varepsilon} \nabla \times \vec{H} \\
& \frac{\partial \vec{H}}{\partial t}=-\frac{1}{\mu} \nabla \times \vec{E}
\end{aligned}
$$

放射ノイズ源がおかれたグリッド辺では電流密度 $j$ が定 義され, それ以外の箇所では電流密度はゼロである。また 金属などの散乱物体の置かれたグリッド辺では導電率 $\sigma$ が 定義され，それ以外の箇所では PML 層を除いて導電率はゼ ロである。

このような計算領域に対応させた模擬建物を製作した。 その写真を図 6 に示す。模擬建物は, 一辺 $0.6 \mathrm{~m}$ の立方体で, $0.5 \mathrm{~mm}$ 厚のアルミ板を用いている。但し，空のある面だけ は，計算と一致させるために 2 枚のアルミ板を組み合わせ て, 中空構造として $0.03 \mathrm{~m}$ の厚さになるようにしている。 壁と壁の隙間はアルミ製の導電性テープで目貼りをしてい る。内部には一辺 $0.09 \mathrm{~m}$ の矩形ループアンテナを置き，同 軸ケーブルの先端に取り付けた。同軸ケーブルからの分岐 点（給電点）は計算と同じように，アンテナの下辺にとっ てある。壁面にとりつけた BNC 端子を介して外部から同軸 ケーブルでループアンテナに電流を流した。模擬建物は銅 板を敷き詰めた床面から高さ $0.8 \mathrm{~m}$ の木製テーブルに置かれ ている。

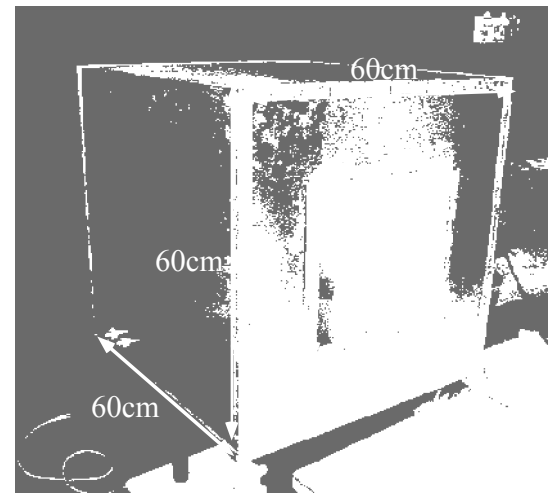

図 6 検証実験に使用した模擬建物の写真

Fig. 6. Photograph of simulated building used for experiment.

図 7 に計算結果と実験結果の比較を示す。周波数が $10 \mathrm{MHz}$ と $1280 \mathrm{MHz}$ の場合について比較した。各々, 波長と建屋長

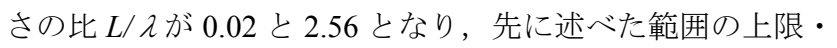
下限にほぼ相当する。計算は領域内の磁界分布が定常にな るまで行った。10MHz の時は 6 周期分(600ns), $1280 \mathrm{MHz}$ の 時は 60 周期分 $(46.8 \mathrm{~ns})$ である。発振アンテナが $\mathrm{y}$ 方向を 向いており, 全般的に $\mathrm{y}$ 方向磁界が最も強くなる。そこで 測定点での磁界の $\mathrm{y}$ 方向成分をフーリエ変換して, $10 \mathrm{MHz}$ 及び $1280 \mathrm{MHz}$ の強度を計算した。実験では手製の直径 $0.015 \mathrm{~m}$ のループアンテナを $\mathrm{y}$ 方向に向け, 出力をスペクト ラムアナライザ（アンリツ M2661A）で計測した。尚, $1280 \mathrm{MHz}$ という值を選んだのは, 発振器に市販のアマチュ ア無線器を選んだためである。10MHz はファンクションジ エネレータ(Sony Tektronix AFG310)を使って正弦波電流を 流した。スペクトラムアナライザの出力が $\mathrm{dB}$ 表示のため, 計算・実験共に，アンテナの中心点での值を基準とする $\mathrm{dB}$ 表示で比較する。

$10 \mathrm{MHz}$ の場合, $\mathrm{y}$ 方向に関しては実験と計算がよく一致 している。 $\mathrm{x}$ 方向に関しても $0.04 \mathrm{~m}$ 付近を除いてはよく一致 している。正方形ループアンテナの一辺が $0.09 \mathrm{~m}$ であるた め, $\mathrm{x}=0.045 \mathrm{~m}$ にアンテナが存在する。計算において $0.4 \mathrm{~m}$ 付 近でピークが出ているのはそのためである。また計算結果 はアンテナを含んだ面( $\mathrm{y}=0)$ において $\mathrm{x}$ 方向に $\mathrm{y}$ 方向磁界強 度をプロットしているが，実験においては，アンテナ同士 がぶつかるため, 測定アンテナを厳密に $\mathrm{y}=0$ におくことは できず，発振アンテナ付近では y 方向に若干ずれたところ を測定している。計算と実験の差が生じているのはこのた めである。測定アンテナを $\mathrm{y}=0$ の面におくのが容易な $\mathrm{x} \geq 0.1 \mathrm{~m}$ のところでは，実験と計算がよくあっている。

$1280 \mathrm{MHz}$ の場合, 波長が模擬建物よりも小さいために, 定在波が発生し， $\mathrm{y}=0.11 \mathrm{~m}$ と $\mathrm{x}=0.23 \mathrm{~m}$ のところに節がある。 測定結果は若干の減少を示すものの, 計算程には落ち込ん でいない。これは受信アンテナの大きさが直径 $0.015 \mathrm{~m}$ であ るために空間分解能が悪く, 計算で現れるような鋭い変化 を捉えきれないためである。そのことを考慮した上で, 図 7 

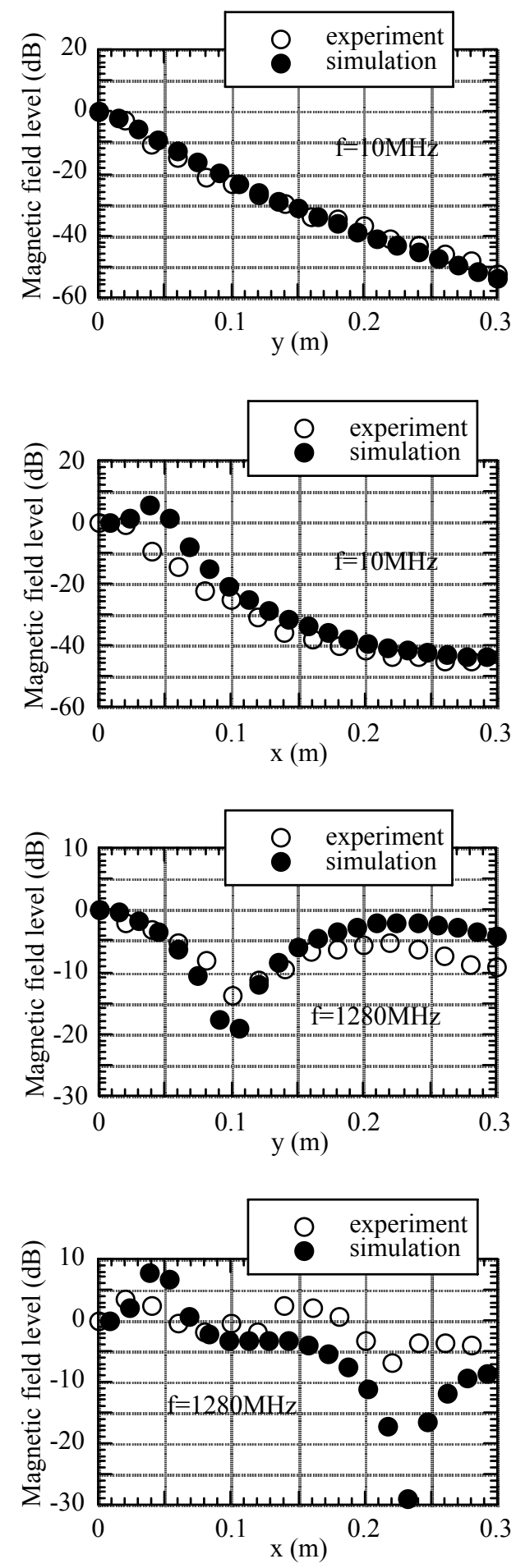

図 7 計算結果と模擬建物での測定結果の比較（アンテナ 中心を通る $\mathrm{x}, \mathrm{y}$ 平面内で $\mathrm{x}, \mathrm{y}$ 軸方向にスキャンした $\mathrm{y}$ 方向磁界強度を示寸)

Fig. 7. Comparison between simulation and the experiment (magnetic field strength in $\mathrm{y}$ direction scanned in $\mathrm{x}$ and $\mathrm{y}$ directions on the $\mathrm{x}-\mathrm{y}$ plane including the center of antenna is shown).

を見ると，計算が定在波の節の位置をよく再現し，それ以 外の場所も概ね測定と一致している。このような比較から
本研究で作成した 3 次元の FDTD コードが, 電磁波発生源 と散乱物体さえ正確にモデル化すれば，順問題を解いて空 間内の電磁界分布を正しく計算できることを確認した。

\section{4. インバータ・モータ系からの放射電磁界の シミュレーション}

次に，実際のインバータ・モータ系から放射される磁界 について FDTD 法を用いてシミュレーションを行って実測 值と比較した結果について述べる。シミュレーションモデ ルを図 8 に示す。対象としたインバータ駆動交流モータは 図 1 に示したものと同じであるが, 設置状況は若干異なっ ており，計算モデルはそれに合わせている。また図 8 中に 示したシールドとはスチール製の衝立 $(0.06 \times 1.25 \times 0.84 \mathrm{~m})$ を使用したものであり，手近に散乱物体があったときの様 子を見られるように設置してある。計算は総グリッド数 70 $\times 70 \times 45$ の領域で行い, $\Delta \mathrm{x}=\Delta \mathrm{y}=\Delta \mathrm{z}=0.06 \mathrm{~m}$ のグリッド幅 とした。境界条件としては $\mathrm{z}=0$ は完全導体を仮定し $, \pm \mathrm{x}, \pm \mathrm{y},+\mathrm{z}$ 方向の境界には 7 グリッドの厚みの PML 層を配置した。シ ールド材の導電率としては $1.3 \times 106 \mathrm{~S} / \mathrm{m}$ を仮定している。シ ールド以外には領域中に導電体はなく, 完全導体の床の上 の開放空間になっている。

2 章で特定したコモンモードノイズ電流経路を放射源と した。具体的には 24VDC 電源からの接地線, 24VDC 電源 とインバータの間の接地線, 机上のブレーカとインバータ 間の 3 相電源線, ブレーカから床までの 3 相電源線である。 これらの線は実験においても, わざと直線状になるように 配線しており，矩形グリッドでのモデル化が容易になるよ うにしてある。インバータとモータ間の接地線にも電流は 流れるが，モータ動力線の電流と打ち消しあっているので, 放射源としては無視した。概形として, 高さ $0.84 \mathrm{~m}$,幅 $0.78 \mathrm{~m}$ の矩形状電流源を仮定した。その電流経路に図 2 に示した ような電流が流れていると仮定して，放射される電磁界を FDTD 法で計算した。シミュレーションで使用した電流波形 は厳密には図 2 とは別のものであるが, 実際に各放射線路 上で電流プローブ(Sony Tektronix P5100)により測定した波 形を用いている。図 8 で電流経路が途中で途切れている箇 所があるのは，そこに機器（インバータとブレーカ）があ るためである。電流を計測するのと同時に図 8 中に示した 測定点(床からの高さ $1.08 \mathrm{~m}$, 机前縁からの距離 $0.36 \mathrm{~m}$ )にて磁 界を計測した。磁界測定は自作のループアンテナをオシロ スコープ(Sony Tektronix TDS380P)につないで行い, 電流プ ローブの出力でトリガをかけた。

シミュレーション及び実測結果を図 9 に示す。3 章では放 射源として検証の容易な矩形ループアンテナを用いて単一 周波数の電流を流したが, 今の場合は実際のノイズ電流波 形を使っているため，多くの周波数が混ざり合っている。 実測值との比較は概ね良好であり，ノイズ放射源となって いる電流経路とそこを流れる電流波形さえ特定すれば, 周 辺の電磁界分布を FDTD 法にて再現可能であることがわか る。またインバータ・モータ系のようにノイズ電流が繰り 


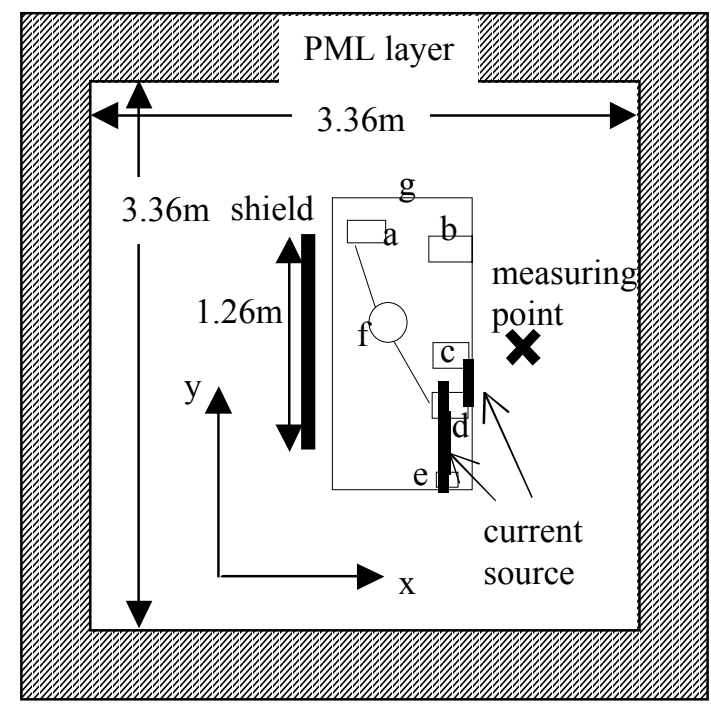

a: motor

b: DC power supply controlling motor speed

c: $24 \mathrm{~V}$ DC power supply for inverter drive

d: 3-phase inverter

e: breaker

f: motor power line

$\mathrm{g}$ : desk
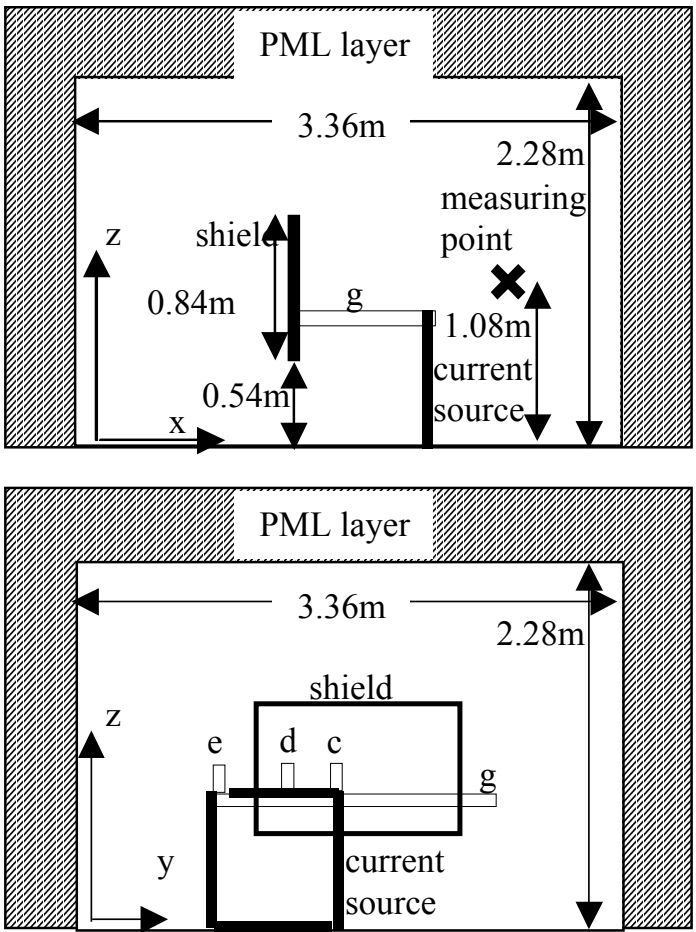

図 8 インバータ・モータシステムからの放射電磁界の

$$
\text { シミュレーションのための計算領域 }
$$

Fig. 8. Computational domain to simulate electromagnetic radiation from an inverter-motor system.

返しのパルスであっても，時間領域で放射ノイズの伝搬を 再現することが可能である。このように，建屋内の電磁界 分布は，放射源が既知である順問題である限り，数值解法 により求めることができる。しかしながら，図 9 にあるよ うに，実測值と計算值の間には未だ若干のずれがある。こ
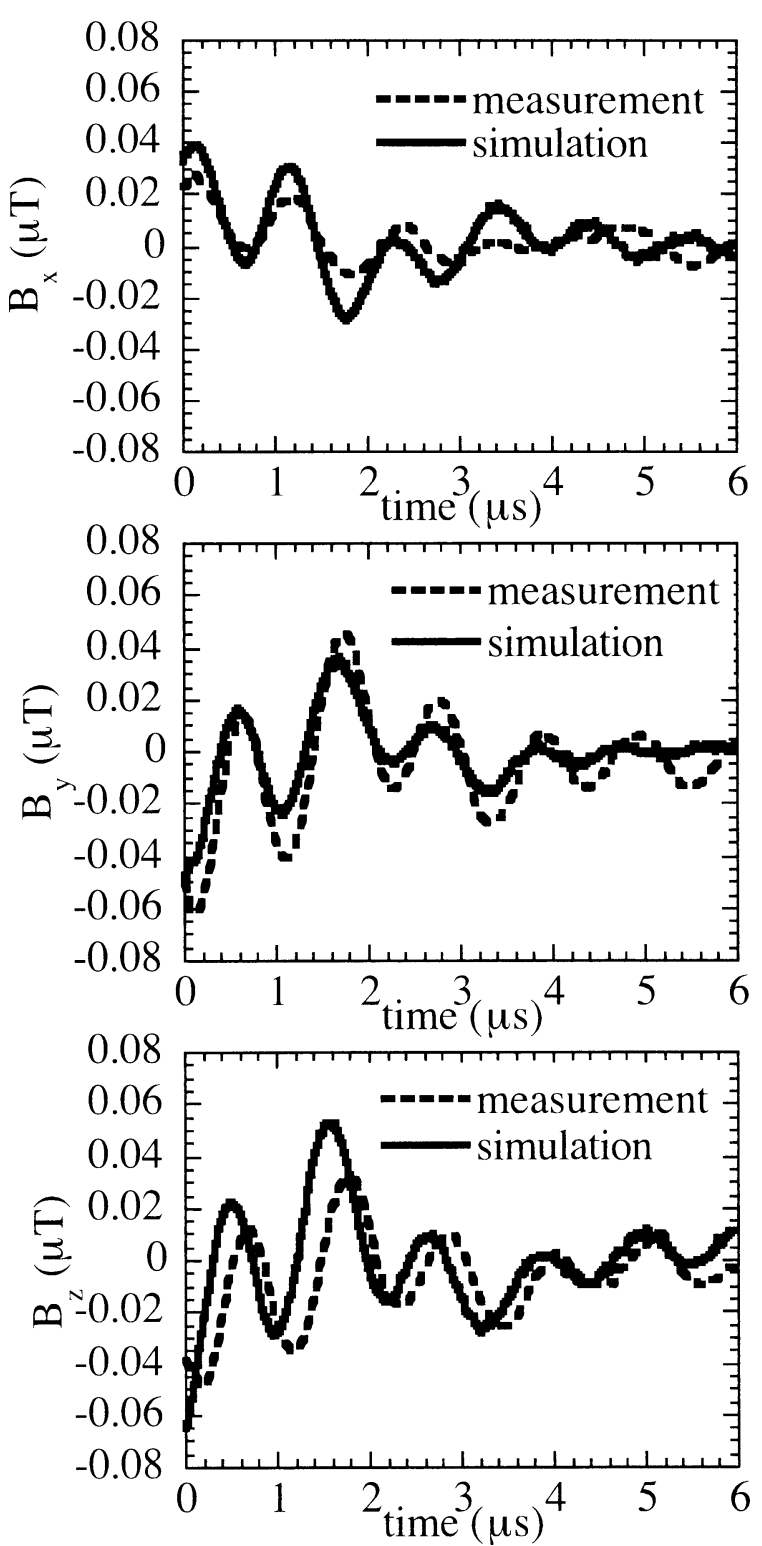

図 9 インバータ・モータシステムからの放射電磁界の

$$
\text { シミュレーション結果と実測結果 }
$$

Fig. 9. Results of simulation and measurement of electromagnetic radiation from an inverter-motor system.

れは，実験をその他の機器（電磁波散乱物体）も存在する 鉄筋コンクリート製の普通の建屋で行ったのに対し，シミ ユレーションを直近の散乱体だけを考慮した非常に単純な モデルで行ったためであると考えられる。次章以降では建 屋内の電磁環境をモデリングする際の課題について述べて いくことにする。

\section{5. 建屋内の電磁環境のモデリング}

この章では, 工場建屋内の電磁環境をモデル化するうえ で，外部境界である壁や空をどこまで考慮する必要がある かを考える。まず，3 章で解析した模擬建物のアルミ板をコ ンクリート壁に変えた場合の結果を図 10 に示す。図の左側 が壁材の導電率を $\sigma=2.3 \times 10^{-3} \mathrm{~S} / \mathrm{m}$ にした場合で, 右側が壁 


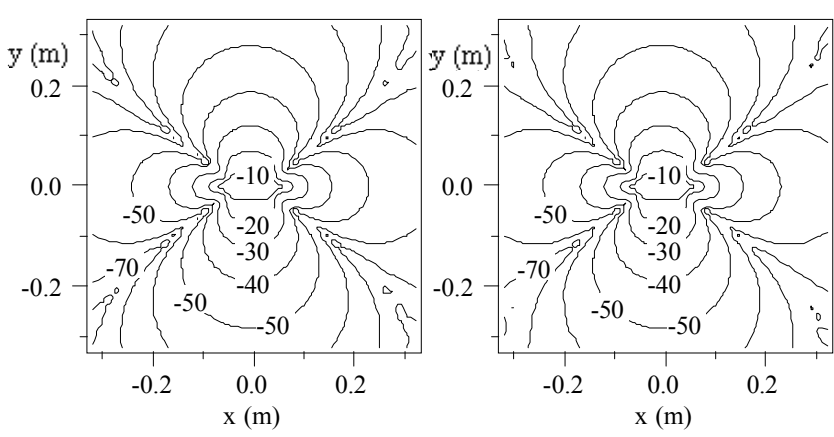

図 10 図 5 の模擬建物の壁を導電率 $\sigma=2.3 \times 10^{-3} \mathrm{~S} / \mathrm{m}$ のコン クリートで置き換えた時（左）と模擬建物の壁を取り払っ た時(右)の模擬建物内の $\mathrm{y}$ 方向磁界強度の分布 (アンテナの 中心を通る $x y$ 平面 $(\mathrm{z}=1.125)$ での分布を示す。等高線は $\mathrm{dB}$ 表示で，平面内の最大值を基準としている)

Fig. 10. Distribution of magnetic field strength in $y$ direction : Left; wall of the simulated building in Fig.5 is replaced by concrete wall with conductivity, $\sigma=2.3 \times 10^{-3} \mathrm{~S} / \mathrm{m}$ : Right ; wall is removed (distribution on $\mathrm{x}-\mathrm{y}$ plane with the antenna center $(\mathrm{z}=1.125 \mathrm{~m})$ is shown. the contour line is in $\mathrm{dB}$ normalised by the maximum value on the plane).

を全く置かない場合である。発振源の周波数は $100 \mathrm{MHz}$ で ある。図を比較すると，両者に違いは殆どなく，建物内部 では最大でも $4 \mathrm{~dB}$, 平均では $0.28 \mathrm{~dB}$ しか差がない。導電率 $\sigma$ を $2.3 \times 10^{-3} \mathrm{~S} / \mathrm{m}$ としたときに，壁の表皮深さは $\delta=\sqrt{\pi f \mu_{o} \sigma}$ より $1 \mathrm{MHz}$ で約 $10 \mathrm{~m}, 10 \mathrm{MHz}$ で約 $3 \mathrm{~m}$ であり,

厚さ $10 \mathrm{~cm}$ 程度のコンクリート壁には殆どシールド効果は なく，電磁波は貫通する。

しかしコンクリート壁中に鉄筋が入ると，鉄筋の間隔と 波長によっては鉄筋が完全導体面と同様の振るまいをする ことがある。このような問題において考慮す心゙き長さの次 元を持ったパラメータとしては，表 1 に示すように建屋の 長さ，波長，鉄筋の太さ，鉄筋の間隔，発振源の長さ，発 振源と壁との距離等，多岐にわたり，波長で無次元化した としても, 最低 5 つの無次元パラメータの組合わせとなる。

FDTD 法を用いると，ある波長の正弦波をモデルするの に，一波長内にグリッドが最低でも 4 個は必要である。そ のため鉄筋の太さのように非常に小さなパラメータを模擬 しなければならない時は, グリッド幅は必然的に小さなも のとなり，例えば表 1 の鉄筋太さの下限 $\left(d_{w} / \lambda=3 \times 10^{-5}\right)$ と 発振源長さの上限 $\left(L_{a} / \lambda=30\right)$ を単一のグリッド幅を用いて両 立させるような計算は，現在の計算機のメモリ容量では不 可能に近い。しかしながら, 無次元化パラメータの中間領 域をとるような計算は単一グリッド幅を用いても実行可能 である。図 11 に例として行った計算モデルを示す。計算領 域は 1 グリッドの長さを $0.03 \mathrm{~m}$ として $6.54 \mathrm{~m} \times 6.54 \mathrm{~m} \times 1.47 \mathrm{~m}$ である。建屋の大きさは $6 \mathrm{~m} \times 6 \mathrm{~m} \times 1.2 \mathrm{~m}$ とし, 建屋の床面 は導体面とし, 壁及び天井に $0.3 \mathrm{~m}$ 間隔で金属筋を配置した。
表 1 工場建屋内電磁環境をモデル化するための長さに 関するパラメータ

Table 1. List of parameters with the dimension of length necessary to model the electromagnetic environment inside a factory building.

\begin{tabular}{|l|l|l|l|}
\hline parameters & Symbol & range $(\mathrm{m})$ & $\begin{array}{l}\text { range of parameters } \\
\text { non-dimensionalized } \\
\text { by wave length }\end{array}$ \\
\hline wavelength & $\lambda$ & $30 \sim 300$ & 1 \\
\hline $\begin{array}{l}\text { length of } \\
\text { building }\end{array}$ & $L$ & $10 \sim 100$ & $0.03 \sim 3$ \\
\hline thickness of wire & $d_{w}$ & $0.01 \sim 0.10$ & $3 \times 10^{-5} \sim 3 \times 10^{-3}$ \\
\hline $\begin{array}{l}\text { gap between } \\
\text { wires }\end{array}$ & $L_{w}$ & $0.1 \sim 1$ & $3 \times 10^{-4} \sim 0.03$ \\
\hline length of source & $L_{a}$ & $0.1 \sim 1000$ & $3 \times 10^{-4} \sim 30$ \\
\hline $\begin{array}{l}\text { Source-wall } \\
\text { distance }\end{array}$ & $d_{a}$ & $0.1 \sim 100$ & $3 \times 10^{-4} \sim 3$ \\
\hline
\end{tabular}

金属筋は断面が $0.03 \mathrm{~m} \times 0.03 \mathrm{~m}$ の矩形棒であり, 床面と金属 筋の導電率は $6.5 \times 10^{7} \mathrm{~S} / \mathrm{m}$ とした。この建屋の中に中心部に 一辺 $0.9 \mathrm{~m}$ の正方形のループアンテナを図 5 と同様に $\mathrm{y}$ 軸に 面して置き, $10 \mathrm{MHz}$ の正弦波電流を $\mathrm{x}=\mathrm{y}=0, \mathrm{z}=0.15 \mathrm{~m}$ の座 標を給電点として流した。図 11 では建屋の壁と天井にある 金属筋の位置を示している。これは所謂ファラデーケージ と同様のものであり，波長が格子間隔よりも長ければ電磁 界を通さないのは周知の事実であるが，本稿では電磁界の 透過ではなく, 建屋内部での反射パターンの違いについて 調べている。

計算は時間刻み幅 $\Delta \mathrm{t}=0.01 \mathrm{~ns}$ で 60,000 ステップ（即ち $600 \mathrm{~ns}$ ）行い, メモリ容量は 4GB で, ベクトルスーパーコン ピュータを用いてベクトル化率 93\%で約 2 時間であった。 並列化はしておらず CPU は一個のみ使用した。この計算は, 数百万円のデスクトップワークステーションを使ったとし てもメモリさえ大量に積んでいれば何とか数日で実行可能 な範囲である。これよりも大きくなって， $60 \mathrm{~m} \times 60 \mathrm{~m} \times 12 \mathrm{~m}$ 規模の大型の建屋を $0.03 \mathrm{~m}$ のグリッドで区切ろうとすると テラバイトクラスのメモリ容量を必要とし, 現状では不可 能である。しかし，これから述べるように，格子状の鉄筋 を単純な導体面で置き換えることが可能であれば，グリッ ドを鉄筋の太さ程度まで細かくする必要はなく, 現在のワ ークステーションクラスのコンピュータでも十分に解析は 可能になる。

図 11 に示した建屋内での $10 \mathrm{MHz}$ の電磁界の分布と, 建 屋の壁及び天井を導体で置き換えて完全遮蔽としたときの 電磁界の分布を比較した。図 12 に $\mathrm{x}=0, \mathrm{y}=0.6 \mathrm{~m}, \mathrm{z}=0.6 \mathrm{~m}$ で の $\mathrm{y}$ 方向磁界成分の時間変化を示す。

図 12 は上段が金属筋の時の磁界 $H_{\text {wire }}$ で, 下段が壁面を全 て金属面として完全遮蔽とした時の磁界 $H_{p s}$ である。どちら も発振周波数である $10 \mathrm{MHz}$ での振動を見せているが，金属 面壁の場合は高周波成分が重畳されたようになっている。 FDTD 法においては，時間的にも差分を取っている関係上， 完全な単一周波数の正弦波を作ることはできず，各時間ス 


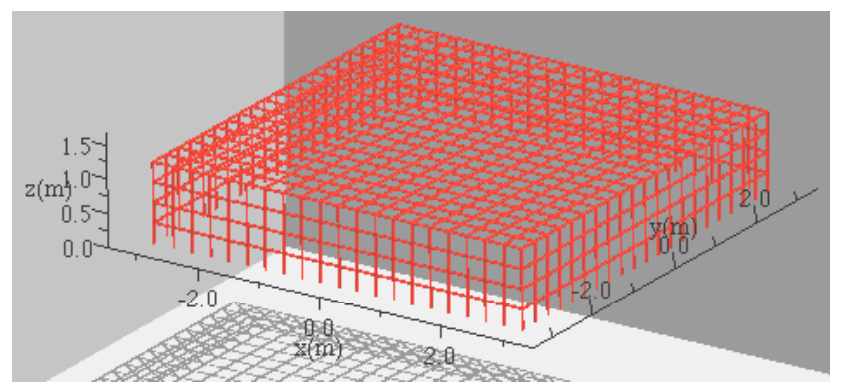

図 $116 \mathrm{~m} \times 6 \mathrm{~m} \times 1.2 \mathrm{~m}$ の建屋を太さ $0.03 \mathrm{~m}$ の金属筋を $0.3 \mathrm{~m}$ 間隔で入れた壁で覆った建屋の計算モデル

Fig. 11. Computational model of $6 \mathrm{~m} \times 6 \mathrm{~m} \times 1.2 \mathrm{~m}$ building with wall which has wires of $0.03 \mathrm{~m}$ thickness at $0.3 \mathrm{~m}$ interval.
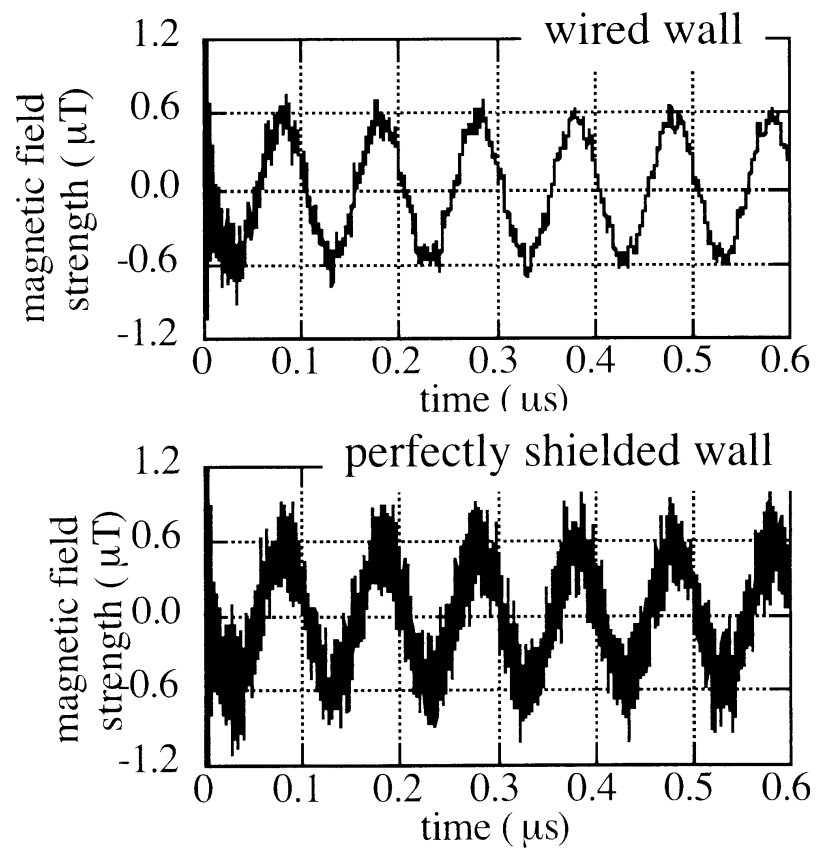

図 12 図 11 に示した計算領域中での $\mathrm{x}=0, \mathrm{y}=0.6 \mathrm{~m}, \mathrm{z}=0.6 \mathrm{~m}$ での $\mathrm{y}$ 方向磁界の時間変化 (上), 図 11 と同じ大きさの建屋 を金属壁で覆って完全遮蔽した時の同じ場所での $\mathrm{y}$ 方向磁界の時間変化（下）

Fig. 12. Temporal variation of magnetic field in $y$ direction at $\mathrm{x}=0, \mathrm{y}=0.6, \mathrm{z}=0.6 \mathrm{~m}$ in the computational domain shown in Fig.11 (top), temporal variation of magnetic field in y direction at the same position when the building is covered by simple metallic walls (bottom).

テップ毎に変化する階段波のようなものになる。そのため, 電磁界には高周波成分が含まれることになる。金属筋入り の場合，高周波成分は金属筋壁の隙間から外部に抜けてい き，金属筋が高域通過フィルターとして働いて，内部の電 磁界は図 12 の上にあるように滑らかな低周波振動だけが残 る。一方金属面で完全密閉すると高周波成分は建屋の外に 逃れられず，図 12 の下のように主周波数に重畳された形を

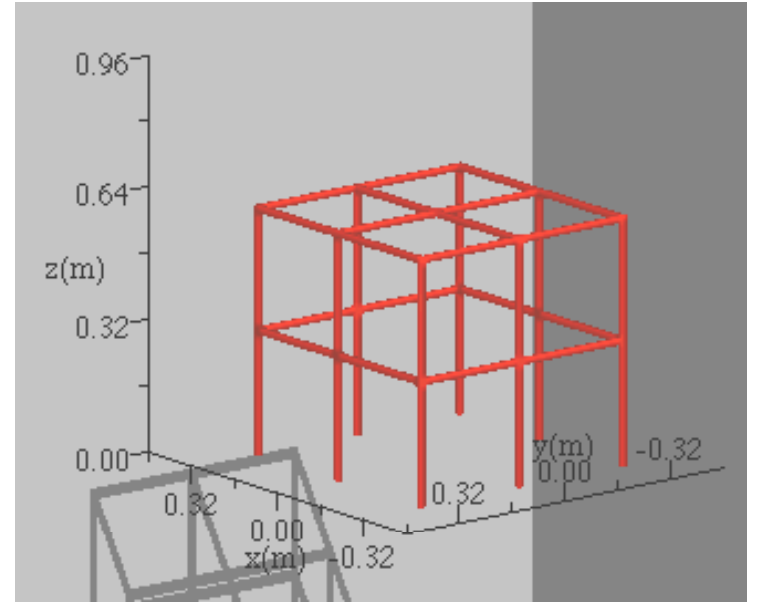

図 13 波長と金属筋の間隔の関係を調べるために用いた 模擬建物の計算モデル

Fig. 13. Computational model of simulated building used to study the relationship between wavelength and the gap of wires.

とる。実際の測定においては，スペクトラムアナライザを 用いて各周波数成分毎の強度を見ることが多いので，今の ように $1 \mathrm{MHz} 10 \mathrm{MHz}$ 成分だけを注目するのであれば，その 部分の強度は壁面が完全遮蔽の金属面であろうが，鉄筋コ ンクリートであろうが，大差はない。

どれくらいの波長まで鉄筋コンクリートを金属壁で置き 換え可能かを調べるために，図13 のような計算領域におい て波長を $0.15 \mathrm{~m}$ から $30 \mathrm{~m}$ まで変化させて, 内部の電磁界分 布が壁を金属面で置き換えたときとどれくらい違ってくる かを調べた。計算領域はグリッド幅を $0.015 \mathrm{~m}$ として， $50 \times$ $50 \times 57$ の計算領域 $(\mathrm{PML}$ 層を除く)で行い， $\pm \mathrm{x}, \pm \mathrm{y},+\mathrm{z}$ 方 向には 7 グリッドの PML 層を付加している。 $\mathrm{z}=0$ は完全導 体を仮定し, 太さ $0.015 \mathrm{~m}$ の金属筋 $\quad\left(\right.$ 導電率 $\sigma=6.5 \times 10^{7} \mathrm{~S} / \mathrm{m}$ ) を $0.3 \mathrm{~m}$ 間隔で配置して一辺 $0.6 \mathrm{~m}$ の模擬建物を構成してい る。模擬建物の下面 $(\mathrm{z}=0)$ は完全導体面である。発振源は図 5 と同様に $\mathrm{y}$ 軸方向を向いて模擬建物中央に置き, 給電点を $\mathrm{x}=\mathrm{y}=0, \mathrm{z}=0.255 \mathrm{~m}$ においた 1 辺 $0.09 \mathrm{~m}$ の正方形のループアン テナとしている。ループアンテナに $10 \mathrm{MHz}$ から $2 \mathrm{GHz}$ の正 弦波電流を最低でも 6 周期以上流した。模擬建物内の計算 格子点を $0.06 \mathrm{~m}$ 毎にとった 225 点での磁界の 3 成分を記録 した。計算終了後，225 点で記録された磁界の時間波形を， フーリエ変換し，発振周波数成分の振幅を求めた。各周波 数において, 模擬建物が図 13 に示すような金属筋と完全導 体の床で構成されている場合と, 金属筋の代わりに金属壁 (導電率 $\sigma=6.5 \times 10^{7} \mathrm{~S} / \mathrm{m}$ ) で覆われている場合の 2 通りを計算 し，225点での磁界の振幅を比較した。振幅はそれぞれの場 合の建物内の最大值 $H_{\max }$ を基準とした $\mathrm{dB}$ 表示 $20 \log _{10}\left(H / H_{\max }\right)$ で表す。

図 14 に周波数 $100 \mathrm{MHz}$ の時の $\mathrm{xy}$ 平面での $\mathrm{y}$ 方向磁界分 布を示すが，両者がよく一致しているのがわかる。図 14 の 左側から右側を引いて絶対值をとると, 図 15 になる。これ 

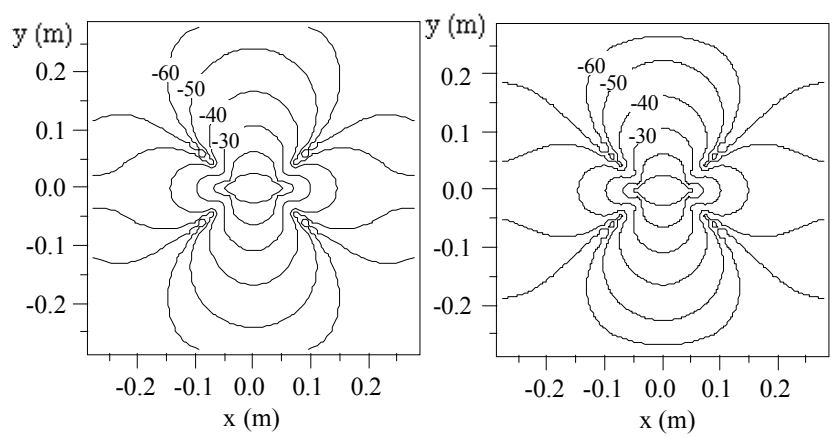

図 14 模擬建物内 $\mathrm{z}=0.3 \mathrm{~m}$ の $\mathrm{xy}$ 平面内での $100 \mathrm{MHz}$ の $\mathrm{y}$ 方向磁界の強度分布（最大值を基準とした $\mathrm{dB}$ 表示で表し， $10 \mathrm{~dB}$ 毎の等高線を示す。発振源の位置は $\mathrm{y}=0$ 。左 ; 壁を 図 13 のような金属筋とした時，右；壁を金属面とした時）

Fig. 14. Distribution of $y$ direction magnetic field on $\mathrm{x}-\mathrm{y}$ plane at $\mathrm{z}=0.3 \mathrm{~m}$ inside the simulated building (contour lines are in every $\mathrm{dB}$ normalised by the maximum value. Left; metallic wire wall like Fig. 13. Right; simple metallic wall).

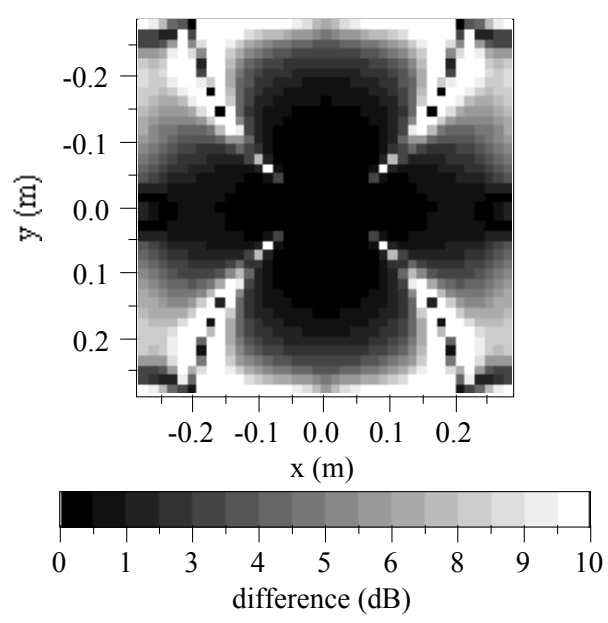

図 15 図 14 の左右の差の絶対值の分布

Fig. 15. Distribution of absolute value of difference between the left and right figures in Fig.14.

より，壁を金属面としても金属筋としても殆どの場合差は 数 $\mathrm{dB}$ 以内であることがわかる。元々の磁界が小さなところ では比較的大きな差が生じているが，実際の測定でもノイ ズ源からの磁界が弱いと背景磁界に埋もれてしまうので, 磁界の弱いところのずれは無視できると思われる。

磁界波形を記録した 225 点において, 各点の磁界強度と, 金属筋と金属壁の差をプロットしたものを図 16 に示す。図 16 から, 両者の差が士 $1 \mathrm{~dB}$ 以上に拡がるのはその点の磁界 強度が 40dB 程低下してからであるのがわかり, 発振源の近 傍の磁界の強いところでは殆ど差がないことがわかる。

波長が短くなると電磁界が金属筋の隙間を通り抜けてい くので，両者の差が無視できなくなる領域が拡がり，発振 源近くの磁界の強いところでも相当のずれが見られる。図 17 に波長を横軸にして, 縦軸に, 金属壁と金属筋で $\pm 1 \mathrm{~dB}$

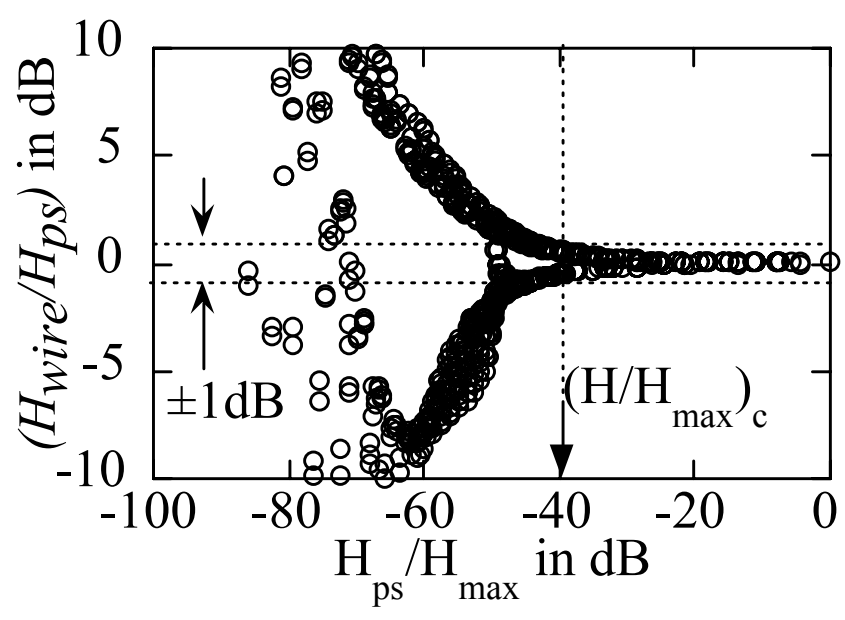

図 16 模擬建物内の空間の 225 点における $\mathrm{y}$ 方向磁界強度 と壁を金属筋と金属壁にしたときの差 (横軸は金属壁の時の 磁界強度を示す，周波数は 100MHz)

Fig. 16. Difference of $\mathrm{y}$ direction magnetic field strength at 225 points inside simulated building between the cases of wired wall and shielding wall (the horizontal axis is the magnetic field strength for the case of shielding wall, the frequency is $100 \mathrm{MHz}$ ).

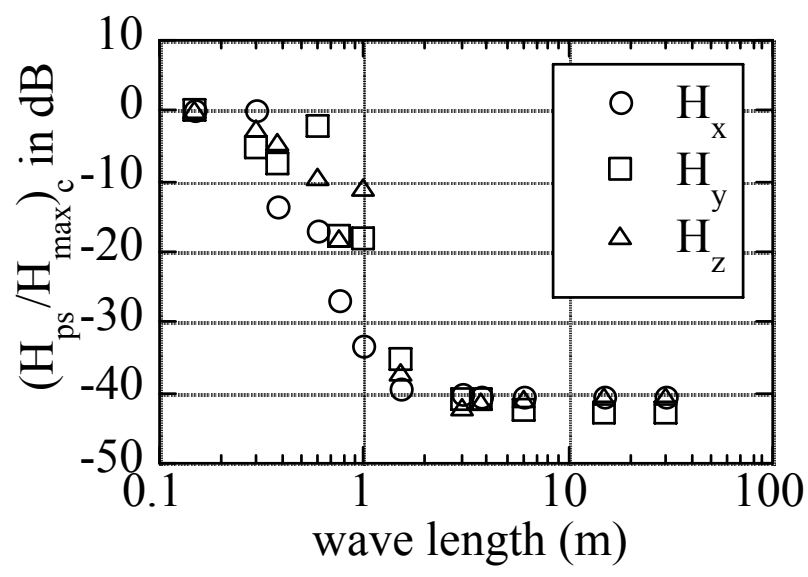

図 17 各波長における，金属筋と金属壁による模擬建物内 の磁界強度の差が $1 \mathrm{~dB}$ を超える点の磁界強度 $\left(H_{p s} / H_{\max }\right)_{c}$

$$
\text { （その定義は図 } 16 \text { に示されている） }
$$

Fig. 17. Magnetic field strength, $\left(H_{p s} / H_{\max }\right)_{c}$, where the difference between the wired and shielding walls exceeds $\pm 1 \mathrm{~dB}$ difference at various wavelength (the definition of horizontal axis is shown in Fig.16).

を超える差がでだす磁界強度 $\left(H_{p s} / H_{\max }\right)_{c}$ をプロットする。図 より，金属筋の間隔 $0.3 \mathrm{~m} の 4$ 倍 $(1.2 \mathrm{~m})$ 程度の波長からずれ が無視できなくなり, 金属筋閒隔と同程度にまで波長が短 くなると模擬建物内の磁界分布は全く異なったものとな る。反対に本研究で対象とするような $30 \mathrm{~m}$ 超の長波長では 壁中の網目上の金属筋をただの金属板で置き換えても模擬 建物内の電磁界分布に影響を与えないことがわかる。

鉄筋入り壁の単純金属壁による置き換えは, 発振源が壁 

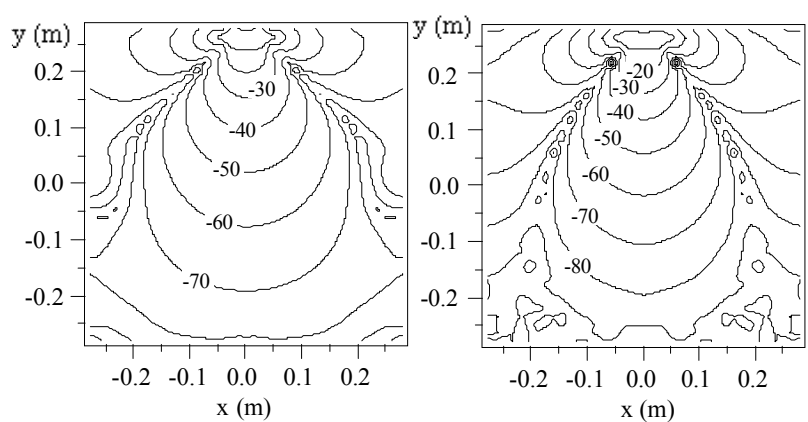

図 18 模擬建物内 $\mathrm{z}=0.3 \mathrm{~m}$ の $\mathrm{xy}$ 平面内での $100 \mathrm{MHz}$ の $\mathrm{y}$ 方向磁界の強度分布 (最大值を基準とした $\mathrm{dB}$ 表示で, $10 \mathrm{~dB}$ 毎の等高線を示す。発振源位置は $\mathrm{y}=0.27 \mathrm{~m}$, 左 ; 壁を図 13

のような金属筋とした時。右 ; 壁を金属面とした時)

Fig. 18. Distribution of magnetic field strength in $y$ direction on $x-y$ plane with the center of antenna at $\mathrm{z}=0.3 \mathrm{~m}$ inside the simulated building for $100 \mathrm{MHz}$ (contour lines are in every $10 \mathrm{~dB}$, the radiation source is at $y=0.27 \mathrm{~m}$, Left; wired wall like Fig. 13 , Right; shielding wall.

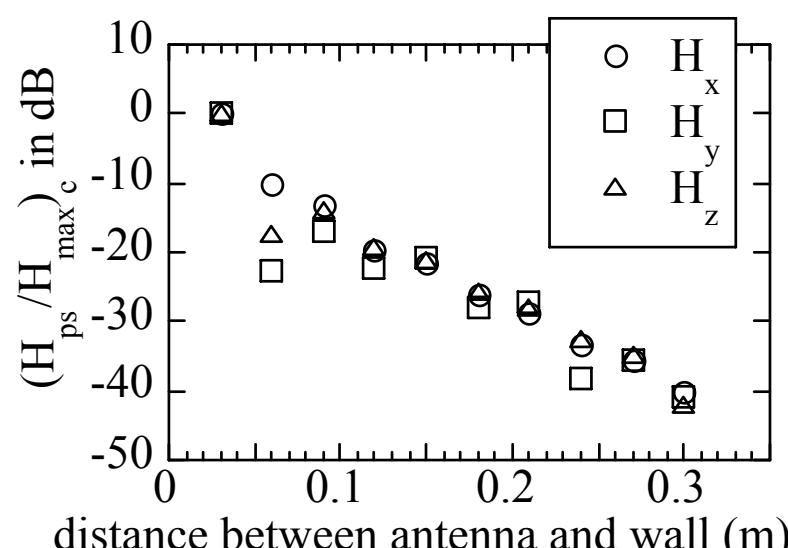

図 $19100 \mathrm{MHz}$ において発振アンテナと壁の間の距離を 変えた時の, 金属筋と金属壁による模擬建物内の磁界 強度の差が $\pm 1 \mathrm{~dB}$ を超える点の磁界強度 $\left(H_{p s} / H_{m a} x\right)_{c}$

(その定義は図 16 に示されている)

Fig. 19. Magnetic field strength, $\left(H_{p s} / H_{\max }\right)_{c}$, where the difference between the wired and shielding walls exceeds $\pm 1 \mathrm{~dB}$ difference for various distance between the noise source and the wall (the radiation frequency is $100 \mathrm{MHz}$. The definition of vertical axis is shown in Fig.16).

から離れている時は成り立つが，発振源が壁に近づくと 個々の金属筋からの反射の影響が発振源近傍の磁界の強い ところでも現れるため, 成り立たなくなってくる。図 18 に 図 13 に示す模擬建物内で, 発振アンテナを $\mathrm{y}=0.27 \mathrm{~m}$ のとこ ろに置いた場合の，模擬建物内の $\mathrm{y}$ 方向の磁界分布を示す。 左側が金属筋の場合で，右側が金属面の時である。全体的 な磁界分布の形状に違いはないが，発振源から遠ざかるに

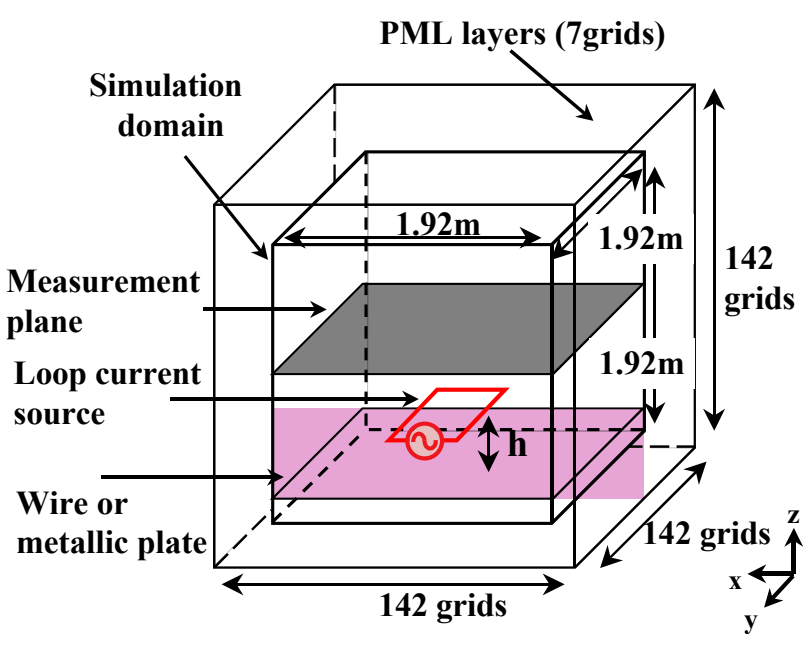

図 20 床中の電源線からの放射を調べるための計算領域

Fig. 20. Computational domain used to study radiation from power lines embedded in floor.

つれての金属筋(左)の方が磁界が緩やかに減衰する。

発振アンテナを $\mathrm{y}$ 軸方向に $0.03 \mathrm{~m}$ ずつずらしていき, $\mathrm{y}=0.3 \mathrm{~m}$ にある壁に近づけていった時に, 金属筋と金属壁で どれくらい差がでるかを調べた。図 19 に図 17 と同様に両 者の差が $1 \mathrm{~dB}$ を超えた時の磁界強度を示す。発振源が壁に 近づくにつれずれが大きくなるのが明らかである。

実際の建屋においては, 電源線の配線は壁や床内で行わ れることが多い。そのため電源線と鉄筋の距離はせいぜい 壁や床の厚み程度しかない。2 章や 4 章でも述べたようにコ モンモードノイズ電流は電源線を介して流れていくことが 多くある。そこで, 放射源が壁や床に埋め込まれているよ うな場合でも鉄筋を金属壁で置き換えられるかどうかを調 ベることとした。図 20 に計算領域を示す。目的が床（壁） 内の放射源に金属筋または金属面が隣接した時の（屋内） 反射パターンの違いを見ることなので，これまでのような 模擬建物とはせず，開放空間内の反射面近傍に放射源をお いた場合の電磁界分布を調べた。計算領域の境界は 6 方向 全て 7 層の PML による吸収境界条件としている。グリッド 幅は $0.015 \mathrm{~m}$ として典型的な鉄筋の径程度とした。金属筋間 隔としては, $0.3 \mathrm{~m}, 0.21 \mathrm{~m}, 0.12 \mathrm{~m}$ の 3 通りを考えた。尚, 建築基準法により鉄筋間隔は $0.3 \mathrm{~m}$ 以内と決められている。

例として図 21 に間隔を $12 \mathrm{~cm}$ とした時の金属筋の配置を 示す。放射源が床中に埋もれていることを仮定して金属筋 または金属面から $0.03 \mathrm{~m}$ 離して全長 $0.48 \mathrm{~m}$ の矩形状ループ 電流源を置いた。 $0.03 \mathrm{~m}$ という距離は床や壁の厚みからし て, 電源線が中の鉄筋線からもつとも離れる距離として選 んだ。電流源に $10 \mathrm{MHz}$ の正弦波電流を 6 周期流し, 床から $1.2 \mathrm{~m}$ 離れた $\mathrm{xy}$ 平面上の 441 点で $\mathrm{z}$ 方向磁界の $10 \mathrm{MHz}$ 成分 の振幅を計算し，磁界分布が床中の金属筋を金属面で置き 換えた時にどうなるかを調べた。尚, 金属筋から $1.2 \mathrm{~m}$ とい う距離は，金属筋が床中にあると想定した時のアンテナを 立てて測定する高さの典型值として選んだ。金属筋と金属 


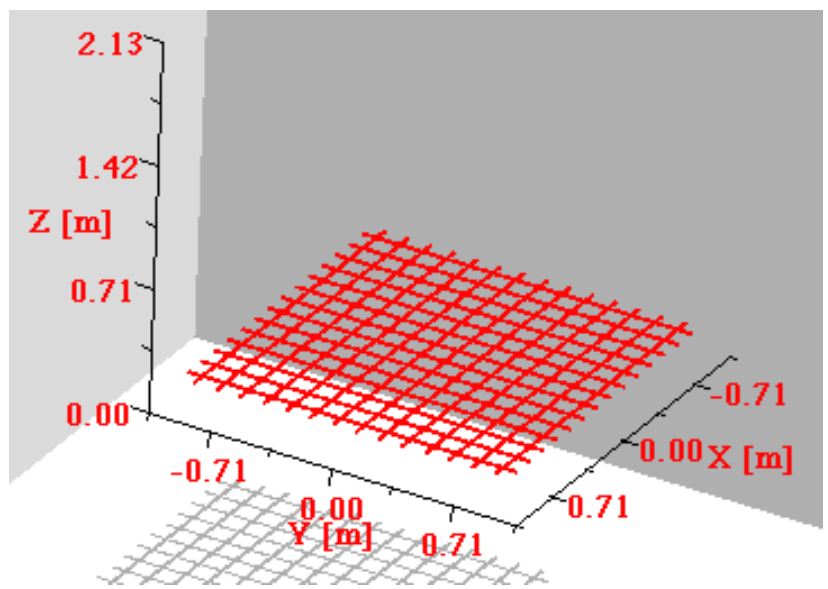

図 $210.12 \mathrm{~m}$ 間隔の金属筋が床にあると仮定した時の 金属筋の配置

Fig. 21. Reinforcing bars inside floor at intervals of $0.12 \mathrm{~m}$.

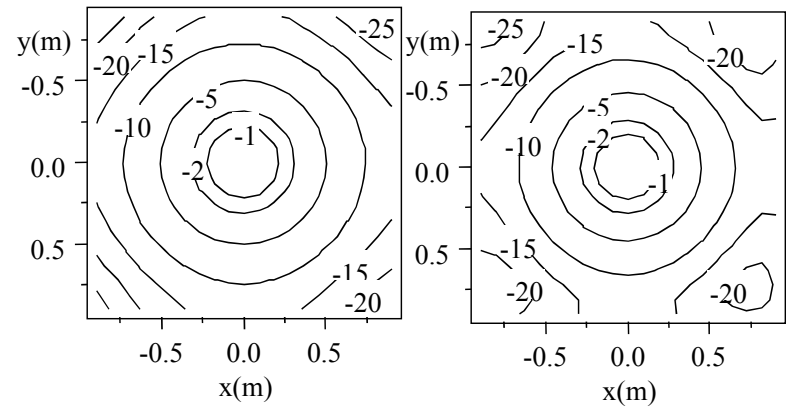

図 22 図 20 に示した領域中で床から高さ $1.2 \mathrm{~m}$ の $\mathrm{xy}$ 平面内 での $10 \mathrm{MHz}$ の $\mathrm{z}$ 方向磁界の強度分布（最大值を基準とした $\mathrm{dB}$ 表示で表す。左 ; 床を間隔 $0.3 \mathrm{~m}$ の金属筋とした時, 右 ; 床を金属面としたとき)

Fig. 22. Distribution of $z$ direction magnetic field of $10 \mathrm{MHz}$ on $\mathrm{x}-\mathrm{y}$ plane at the height of $1.2 \mathrm{~m}$ from the floor shown in Fig.20 (shown in $\mathrm{dB}$ normalized by the maximum value, Left; The floor is made of reinforcing bars at intervals of $0.3 \mathrm{~m}$, Right; The floor is made of simple metallic plate).

面の導電率は共に $\sigma=6.5 \times 10^{7} \mathrm{~S} / \mathrm{m}$ である。

図 22 に金属筋間隔が $0.3 \mathrm{~m}$ の時の結果を示す。床から $1.2 \mathrm{~m}$ 離れた $\mathrm{xy}$ 平面の $\mathrm{z}$ 方向磁界強度を示しており, 平面内の最 大值を基準とした $\mathrm{dB}$ 表示で示す。両者共に床からの反射磁 界が同心円状に拡がっているが，金属筋の時（図 22 の左） の方が，より拡がりが大きい。図 22 の両者の差をとると最 大で $6.2 \mathrm{~dB}$ の差があり, 平均でも $1.6 \mathrm{~dB}$ の差がある。図 23 には鉄筋の間隔を変えた時の 441 点の差の平均, 最大值, 最小值を示す。鉄筋間隔が狭まると誤差が小さくなるが, 鉄筋間隔が $12 \mathrm{~cm}$ となっても未だ最大 $4 \mathrm{~dB}$ の差が残ってい る。このことから，放射源が壁や床の中に埋め込まれてい るような場合は，鉄筋の一本ずつをモデル化しなければい

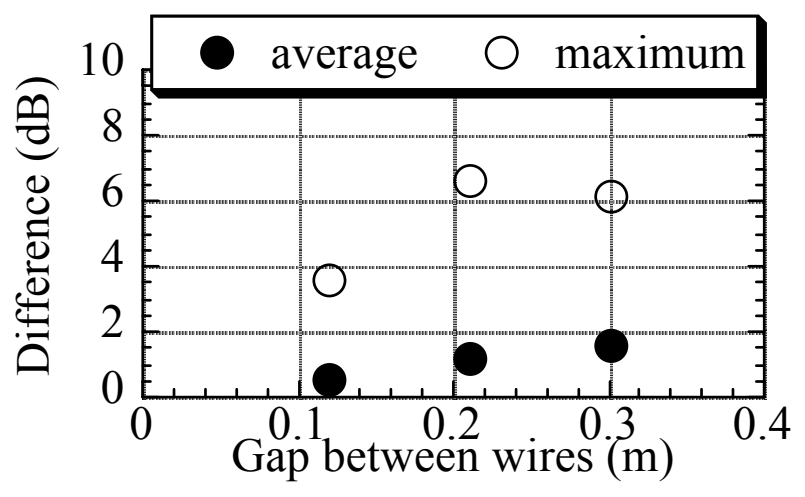

図 23 図 20 に示した領域中で床から高さ $1.2 \mathrm{~m}$ の $\mathrm{xy}$ 平面 の 441 点における $10 \mathrm{MHz}$ の $\mathrm{z}$ 方向磁界の強度について 床を金属筋とした時と金属面とした時の差

Fig. 23. Difference of $\mathrm{z}$ direction of magnetic field between the cases of wire floor and metallic plate floor at 441 points on the xy plane at the height of $1.2 \mathrm{~m}$ from the floor shown in the domain in Fig.20. The frequency is $10 \mathrm{MHz}$.

grid line denoting space $(\sigma=0)$

grid line denoting reinforcing wire $(\sigma \neq 0)$

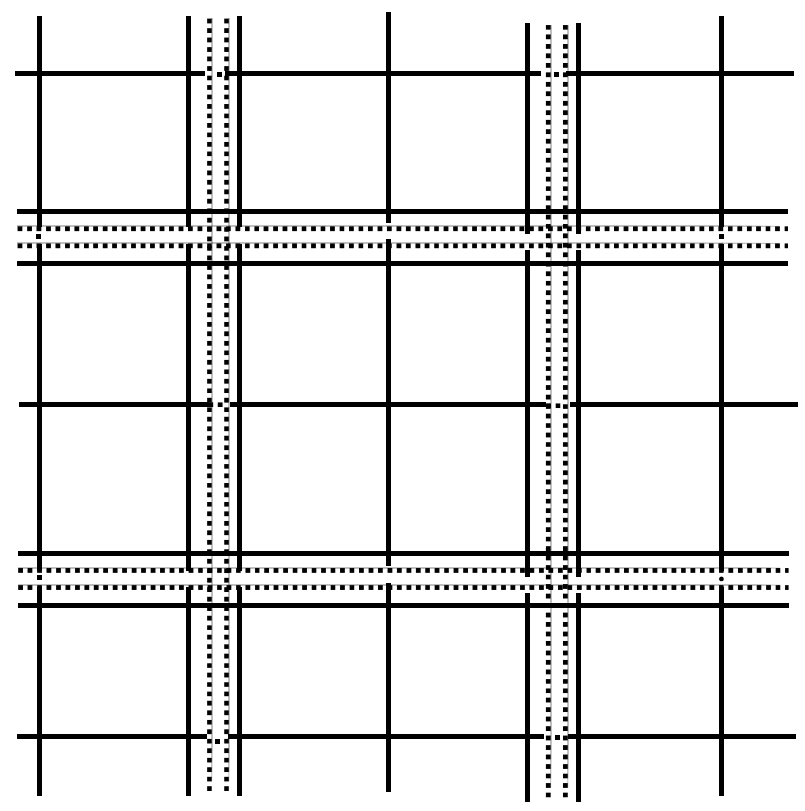

図 24 グリッド幅を鉄筋周辺とそれ以外で分けた グリッド分割法

Fig. 24. Grid division scheme with different grid spacings for reinforcing wires and others.

けないと結論づけられる。

現実的な大きさの建屋内の電磁環境をモデル化する上 で，鉄筋の一本ずつをモデル化しなければならないとした 
ら，単一のグリッド幅を使うと現在のコンピュータ容量で は不可能なことは前述した通りである。単一のグリッド幅 では図 11 に示すような数 $\mathrm{m}$ の大きさの建屋が限界である。 しかし，図 24 に示すようにグリッド幅を鉄筋周辺とそれ以 外で変えることで，散乱物体としての鉄筋と，高周波電磁 波の抜け道としての鉄筋間の両方をモデル化することは可 能である。FDTD 法では電界, 電流, 導電率はグリッドの辺 の中点で定義される。図の例では点線で示したグリッド線 の上では導電率を鉄筋と同じとし，それ以外のところは何 もない空間として導電率はゼロと設定する。但し, 図 24 に 示すようなグリッド構成にした場合でも本稿で示した単一 グリッド幅の時のような定量的な正確さが保てるかどうか は不明であり，計算コードを再度検証する必要がある。ま た，数多くの鉄筋を自動的にモデル化するためのツールも 必要となる。

\section{6. まとめ}

$\mathrm{FA}$ 機器を多用する工場建屋内の電磁環境をモデル化する ために FDTD 法を適用することを考えた。インバータ・モ ータからなるシステムからはインバータのスイッチングに 起因して $1 \mathrm{MHz} 10 \mathrm{MHz}$ のコモンモードノイズ電流が発生す ることを実験で確認し, 伝導路が長ければ電流の周波数帯 を主成分とした放射ノイズが空間内を伝搬することを確認 した。放射ノイズ磁界の建屋内での強度分布を FDTD 法で モデル化するに際し, 実際の建屋を数 10 分の 1 に縮小した 模擬建物内での磁界強度分布を実際の測定と計算結果を比 較することで，計算コードの正確さを検証した。また，伝 導路とそこを流れる電流波形さえ特定すれば周辺電磁界分 布を正確に知ることが出来ることを，実際のインバータ・ モータシステムを用いて検証した。

建屋の壁が鉄筋コンクリートでできていると仮定する と, コンクリートの部分は対象とする周波数域に対しては 殆ど影響を及ぼさず，コンクリート部分は何もない空間で 模擬できることが分かった。鉄筋のような格子状に交差し た金属筋が壁に入ると, 波長が鉄筋の間隔の数倍以上あり 且つ発振源が壁から十分に離れていれば，発振源に近いと ころの磁界を見ているかぎり，壁を単純な金属面に置き換 えた時と同じ磁界分布を示す。ノイズ周波数を $1 \mathrm{MHz} 10 \mathrm{MHz}$ とすると, 通常の鉄筋閒隔よりも波長は遥に 長く，ノイズ源が壁より離れているかぎり壁はただの金属 面で置き換えてモデル化することができる。これにより， 鉄筋の太さ $(0.01 \sim 0.1 \mathrm{~m})$ 程度まで小さな計算グリッドを使 わずとも, 建屋内の電磁環境のモデル化が可能となり, 現 在の数ギガバイトのコンピュータ容量でも単一幅のグリッ ドを使って実際の建屋内の全空間を簡単にモデル化するこ とは可能である。

しかし, 多くの建屋では電源線は壁や床に埋め込まれて おり，インバータ・モータシステムのコモンモードノイズ 電流が電源線に流れでることを考えると，ノイズ電流源が 鉄筋に近接していることが多い。ノイズ源が壁に近いと
個々の金属筋からの反射の影響を受けて, 磁界分布の全体 的な空間分布は金属壁の時と同様でも, 各点での值は発振 源近傍ですら金属壁の時とは異なる。このため, 壁内に放 射源が埋め込まれている時には, 鉄筋を単純な金属壁で置 き換えることはできないことがわかった。このような時に は鉄筋を 1 本ずつモデル化する必要があり, $10 \mathrm{~m}$ を超える 大きさの建屋内の電磁環境の計算は, 単一のグリッド幅を 使う限り数ギガバイト内のメモリで行うことは不可能であ る。

現実的な大きさの建屋をモデル化するには，鉄筋のよう な散乱物体をモデル化するための短いグリッド幅と, $1 \mathrm{MHz} 10 \mathrm{MHz}$ の電磁波の伝搬を表すための長いグリッド幅 の 2 段階にグリッドをわけた多重グリッドが有効であると 思われるが，それらの定量的な正確さについては今後検証 していく必要がある。また多くの散乱物体を自動的にモデ ル化するためのツールも必要となろう。

\section{謝 辞}

本実験及びシミュレーションに協力していただいた本学 卒業生の上杉満隆, 黒川浩司, 陶山晃宏, 角雅章の各氏に 謝意を表します。また, 本研究について貴重な御助言をい ただいた九州工業大学匹田政幸教授と本研究を様々な面で 支えていただいた金森秀一氏を始めとするナスコ株式会社 の皆様に感謝の意を表します。

(平成 14 年 10 月 15 日受付, 平成 14 年 5 月 23 日再受付)

\section{文献}

(1) 宇野 亨:FDTD 法による電磁界及びアンテナ解析, コロナ社 (1998) （2）橋本 修-阿部琢美: FDTD 時間領域差分法入門, 森北出版 (1996)

(3) S. Ogasawara, H. Fujita, and H. Akagi : "Modeling and Analysis of High-Frequency Leakage Currents caused by Voltage-Source PWM Inverters", T. IEE Japan, Vol.115-D, No.1, pp.77-83 (1995-1) (in Japanese)

小笠原悟司・藤田英明・赤木泰文: 「電圧形 PWM インバータが発生 する高周波漏れ電流のモデリングと理論解析」, 電学論 D, 115, 1 , pp.77-83 (1995-1)

(4) S. Ogasawara, H. Ayanno, and H. Akagi : "Measurement and Reduction of EMI Radiated by a PWM Inverter-Fed AC Motor Drive System", T. IEE Japan, Vol.116-D, No.2, pp.1211-1219 (1996-2) (in Japanese) 小笠原悟司・綾野秀樹・赤木泰文:「PWM インバータを用いた交流 電動機駆動システムが発生する EMI の測定とその低減法」, 電学論 D, 116, 2, pp.1211-1219 (1996-2)

(5) S. Sirakawa, N. Mutho, and K. Komatu : "Using Computer Simulations to Analyze Electromagnetic Emissions Generated in PWM Inverter and Motor Drive Systems", T. IEE Japan, Vol.119-D, No.2, pp.195-203 (1999-2) (in Japanese)

白川真司・武藤信義・小松清次 :「計算機シミュレーションによる PWM インバータ・モータ駆動系の電磁波放射特性解析」, 電学論 D, 119, 2, pp.195-203 (1999-2)

(6) K. Uchida, C. Lee, T. Matsunaga, T. Imai, and T. Fujii : "On Ray Tracing Method for Evaluating Field Distribution in Tunnels", T. IEICE Japan, Vol.J82-B, No.5, pp.1030-1037 (1999-5) (in Japanese)

内田一徳・李 昌権・松永利明・今井哲朗・藤井輝也 :「トンネル内 電磁界分布推定のためのレイ・トレース法について」, 通信学論 B, J82-B, 5, pp.1030-1037 (1999-5) 
趙孟 佑 （会員） 1962 年 12 月 19 日生まれ。1991 年 12 月マサチューセッツ工科大学大学院博士課程修 了。1992 年神戸大学大学院自然科学研究所助手。 1995 年 7 月国際宇宙大学 (フランス) 助手を経 て 1996 年 8 月九州工業大学工学部講師, 1997 年 10 月同助教授。高電圧宇宙機と宇宙プラズマ の相互作用に関する研究, レーザ生成プラズマ の工学的応用, 電磁界シミュレーションに関す る研究に従事。Ph.D. 日本航空宇宙学会, アメリカ航空宇宙学会 会員。

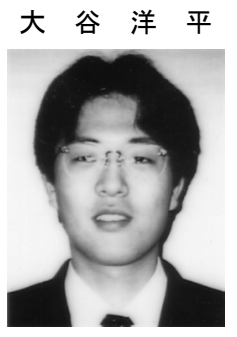

（非会員） 1977 年 4 月 28 日生。 2000 年 3 月, 九州工業大学工学部電気工学科卒業。2002 年 3 月同大学大学院工学研究科博士前期課程修了。 2002 年 4 月新日本製鐵（株）入社, 現在に至る。

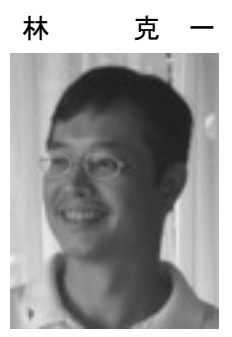

（非会員） 1960 年生まれ。1983 年 3 月慶応大 学経済学部卒業。1991年ナスコ株式会社に入社。 1996 年より同代表取締役社長。 